\title{
BISPECTRAL INDEX (BIS) GUIDED COMPARISON BETWEEN CLINICAL EFFECTS OF ETOMIDATE AND FENT ANYL VERSUS DEXMEDETOMIDINE AND FENT ANYL FOR CONSCIOUS SEDATION IN ERCP PROCEDURE
}

\author{
Arpita Das ${ }^{1}$, Dipasri Bhattacharya 2 , Sankar Roy ${ }^{3}$, Anirban Roy ${ }^{4}$, Mohanchandra Mandal ${ }^{5}$ \\ ${ }^{1}$ Postgraduate Trainee, Department of Anaesthesiology, R. G. Kar Medical College and Hospital, Kolkata, West Bengal, India. \\ ${ }^{2}$ Professor and HOD, Department of Anaesthesiology, R. G. Kar Medical College and Hospital, Kolkata, West Bengal, India. \\ ${ }^{3}$ Assistant Professor, Murshidabad Medical College and Hospital, Murshidabad, West Bengal, India. \\ ${ }^{4}$ Postgraduate Trainee, Department of Anaesthesiology, R. G. Kar Medical College and Hospital, Kolkata, West Bengal, India. \\ ${ }^{5}$ Associate Professor, Department of Anaesthesiology, NRS Medical College and Hospital, Kolkata, West Bengal, India.
}

\section{BACKGROUND}

\section{ABSTRACT}

Endoscopic retrograde cholangiopancreatogram (ERCP) is recently being done under conscious sedation using intravenous anaesthetic agent and fentanyl. Dexmedetomidine, a new alpha 2 agonist with analgesic and sedative effects, is now being used to induce conscious sedation.

The aim of this study was to compare BIS-guided time of onset of conscious sedation and recovery profile, haemodynamic effects, physician/ patient satisfaction score and adverse events if any between patients receiving either etomidate-fentanyl or dexmedetomidine-fentanyl combination for undergoing ERCP procedure.

\section{MATERIALS AND METHODS}

This is a randomised controlled trial. One hundred patients scheduled for ERCP under BIS-guided conscious sedation were rand omly allocated into two equal groups to receive either etomidate-fentanyl (Group E) or dexmedetomidine-fentanyl (Group-D). After premedication with midazolam $(0.05 \mathrm{mg} / \mathrm{kg})$, glycopyrrolate $(0.2 \mathrm{mg})$ and fentanyl $(1 \mathrm{mcg} / \mathrm{kg})$, etomidate or dexmedetomidine were given to the patients allocated to the respective groups to attain a BIS score of 70 . Sedation was maintained throughout the procedure by continuous infusion of these drugs. The time of onset and recovery from sedation, haemodynamic effects, physicians and patient's satisfaction scores, pre- and post-operative serum cortisol and any adverse events were noted in the two groups.

\section{RESULTS}

The time of onset and recovery was earlier in E group ( $p=0.001)$ Incidence of myoclonus was significantly higher in $E$ group $(p=0.022)$. There was higher incidence of hypertension in D group $(p=0.012)$. Physician and patient satisfaction were comparable in both the groups. There was no difference in pre-op and 12-hour post-op serum cortisol in either group.

\section{CONCLUSION}

BIS- guided etomidate-fentanyl for ERCP resulted in earlier onset and recovery from sedation with stable haemodynamics compared with dexmedetomidine-fentanyl.

\section{KEY WORDS}

BIS, Conscious Sedation, Dexmedetomidine, Etomidate, ERCP.

HOW TO CITE THIS ARTICLE: Das A, Bhattacharya D, Roy S, et al. Bispectral index (BIS) guided comparison between clinical effects of etomidate and fentanyl versus dexmedetomidine and fentanyl for conscious sedation in ERCP procedure. J. Evolution Med. Dent. Sci. 2019;8(08):500-505, DOI: 10.14260/jemds/2019/111

\section{BACKGROUND \\ Endoscopic Retrograde Cholangiopancreatography (ERCP) is} a commonly performed diagnostic and therapeutic procedure for various biliary tract and pancreatic diseases. The most significant advantage of this procedure is that it helps avoiding more traumatic and painful open surgical procedures. ${ }^{[1]}$

ERCP is frequently done under general anaesthesia with endotracheal intubation (With Muscle Relaxation).

'Financial or Other Competing Interest': None.

Submission 28-12-2018, Peer Review 12-02-2019,

Acceptance 14-02-2019, Published 25-02-2019.

Corresponding Author:

Sankar Roy,

Phulia, Shantipur,

Nadia, West Bengal, India.

E-mail: dr.sankar.roy2010@gmailcom

DOI: $10.14260 /$ jemds/2019/111

(c) $(i)(9)$
This ensures immobilisation of the patient during the procedure and also helps protecting the airway. Now-a-days ERCP is being done under conscious sedation without muscle relaxation and without intubation. [2]

The most preferred position is semi-prone. In semi-prone position, chest wall compliance is decreased and diaphragm is displaced cephalad due to the increasing intra-abdominal pressure by external pressure applied on abdomen. This leads to a decrease in functional residual capacity and lung compliance, thereby compromising ventilation in anaesthetised or sedated patients. ${ }^{[2,3]}$ Increased intraabdominal pressure decreases the venous return to the heart and predisposes the patient to the risk of hypotension. Maintaining the patient on spontaneous respiration without any upper airway obstruction (Under moderate/conscious sedation) is of utmost importance during the procedure. If the patient stops breathing spontaneously during the procedure, the patient has to be repositioned at the earliest followed by urgent resuscitation. During ERCP the 
gastroenterologist and the anaesthesiologist share a common passage, the upper airway, so airway management can become troublesome at times. ${ }^{[2-5]}$

Every procedure has its own advantages and disadvantages, which are to be carefully judged. The common adverse effects associated with ERCP are nausea, vomiting, throat bleeding and anxiety. Analgesia is also an important factor in the intra and post-operative period. An anxiety-free period before and adequate pain relief after the procedure increases the acceptability of ERCP, as a modality of management of various biliary and pancreatic diseases, amongst patients. ${ }^{[6,7]}$

From anaesthetic point of view, patient positioning (Prone/semi-prone), lack of requirement of muscle relaxation and intubation, common adverse effects of gastroscopy (Nausea, vomiting, anxiety, throat bleed) and sharing a common passage (The upper airway) by the gastroenterologist and the anaesthesiologist, has made ERCP a challenge.

The administration of properly selected anaesthetic agents during ERCP can abolish upper airway reflexes and improve the comfort of patients during the procedure. ${ }^{[7-9]}$

\section{An ideal anaesthetic agent for ERCP should have the following properties: ${ }^{[8,9]}$ \\ - Rapid time of onset and recovery. \\ - Effective throughout the procedure with easy titration of drug delivery. \\ - Minimal adverse effects.}

Conscious sedation is a drug induced depression of consciousness where no interventions are required to maintain the patency of airway with adequate spontaneous respiration and haemodynamic stability.

Etomidate has been used for procedural sedation because of its stable haemodynamic responses and short time of recovery. Dexmedetomidine is short acting and suitable for ERCP procedures because of better patient cooperation, haemodynamic stability and little or no respiratory depression. $[9,10]$ Use any of the two above mentioned drugs have their own merits and demerits.

\section{Reasons Behind Selection of This Study-}

1. Paucity of studies regarding ERCP procedures using etomidate/dexmedetomidine.

2. Anaesthesia in ERCP is a challenge.

3. Use of BIS for monitoring proper plane of sedation.

So, this study was done to compare the time of onset and recovery from conscious sedation using etomidate + fentanyl versus dexmedetomidine + fentanyl combination.

Etomidate causes adrenocortical suppression.[7,9] Serum cortisol levels remain within the normal range and dysfunction resolves within 12-24 hours of using the drug. So, estimation of serum cortisol preoperatively and 12 hours later have been included as a parameter of this study.

\section{Aims and Objectives}

Aim of this study was to compare BIS-guided onset and recovery time of conscious sedation, potential complications and physician and patient satisfaction score between two anaesthetic combinations - etomidate + fentanyl and dexmedetomidine + fentanyl in patients undergoing ERCP.

\section{MATERIALS AND METHODS}

This was a randomised controlled trial. One hundred patients scheduled for ERCP under BIS guided conscious sedation were randomly allocated into two equal groups, E (Etomidate + fentanyl) and D (Dexmedetomidine + fentanyl). After premedication with midazolam $(0.05 \mathrm{mg} / \mathrm{kg})$, glycopyrrolate $(0.2 \mathrm{mg})$, fentanyl (1 $\mathrm{mcg} / \mathrm{kg})$, etomidate and dexmedetomidine were given to the patients allocated to the respective groups to attain a BIS score of 70 . Sedation was maintained throughout the procedure by continuous infusion of these drugs. The time of onset and recovery from sedation, haemodynamic effects and any adverse event were recorded. Physicians and patients were surveyed to assess their satisfaction regarding the anaesthetic procedure. Pre- and post-operative serum cortisol were studied. Study was done in Gastroenterology operating room (ERCP room) of a tertiary Medical College \& Hospital from November 2016 to October 2017. All adult patients of ASA physical status I and II undergoing ERCP under conscious sedation during the study period were included fulfilling the inclusion criteria: Sample Size of 100 was taken for convenience.

They were randomised using computer generated random numbers and allocated into two groups, Group E and Group D as follows-

1. Group E: Patients receiving etomidate and fentanyl.

2. Group D: Patients receiving dexmedetomidine and fentanyl.

\section{Inclusion Criteria}

1. ASA physical status I and II of either sex.

2. Body weight: $40-70 \mathrm{~kg}$.

3. Age: $20-60$ years.

\section{Exclusion Criteria}

1. Associated comorbidities (Uncontrolled diabetes mellitus, uncontrolled hypertension, hypotension, morbid obesity, chronic kidney disease, any neurological/ liver disorder, COPD, congestive cardiac failure, low fixed cardiac output disorders, arrhythmias, shock, etc.)

2. Pregnancy and lactation.

3. Anticipated difficult intubation.

4. History of alcohol/ any drug abuse.

5. Uncooperative patients.

6. Patient refusal.

7. Allergy/history of adverse reaction to dexmedetomidine, etomidate and fentanyl

\section{Variables Studied}

\section{- Parameters for Primary Objective}

1. Time required to reach a BIS value of 70 from the beginning of drug infusion.

2. Time required to reach a BIS value of $\geq 90$ after stopping drug infusion.

- Parameters for Secondary Objective

1. Heart rate, NIBP, SpO2, ECG monitoring intraoperatively. 
2. Serum cortisol levels before and 12 hours after the procedure.

3. Myoclonus: yes/ no (Occurred or not)

- PONV (Postoperative Nausea and Vomiting): YES/ NO (Occurred or not)

- VAS (Visual Analogue Scale) score to assess severity of post-operative pain.

4. Physician and patient satisfaction grading (Good/ Fair/Poor)

\section{Methods of Data Collection}

- Detailed history taking.

- Proper clinical examination.

- $\quad$ Pre-procedure review of relevant investigation reports.

- Review of past medical records (If available)

- Intra operative recording of BIS values and vital parameters.

- Recording of any intraoperative adverse events (like Apnoea/ Myoclonus)

- Review of serum cortisol levels (Before and 12 hours after procedure)

- Post-operative nausea/ vomiting and post-operative pain.

- Interview regarding patient and physician satisfaction during post-operative period.

\section{Pre-Procedure Investigations}

1. Haemoglobin.

2. Complete blood counts.

3. Serum urea/ creatinine.

4. Fasting and postprandial blood sugar.

5. Liver function test (Including P-Time/ INR)

6. Serum sodium/ potassium.

7. Serology (HBsAg, anti HCV, HIV)

8. Chest X Ray (PA view)

9. ECG (12 leads)

10. Other targeted investigations (If required)

Gastroenterologists selected the cases that were planned for ERCP procedure on OPD basis, from patients admitted in the Gastroenterology and other wards (In response to referrals done for consultation). A proper pre-anaesthetic check-up was done.

\section{Detailed History Taken-}

1. ASA physical status assessed.

2. METs (Metabolic equivalents) score assessed.

3. Mallampati Score, Mouth Opening, Neck Movement assessed.

4. Presence of any loose tooth/ artificial dentures enquired about.

5. All suspected cases of difficult airway identified.

6. Complete general and systemic examination.

7. All investigation reports and past medical reports evaluated.

8. Any further specific investigations, if thought necessary, ordered and evaluated.

9. All patients were ordered to follow the ASA Fasting Guidelines on the morning of the procedure.

10. Patients were advised about continuing/ avoiding their regular medication (as needed).
11. Patients and their near relatives were counselled thoroughly.

12. Informed written consent was obtained.

On the day of the procedure, patients came to the ERCP room with an attendant. The patients and their near relatives were thoroughly re-counselled regarding the procedure and the anaesthetic technique to be used. Pre-anaesthetic checkup sheet was checked. Boyle's anaesthesia machine and Bain breathing system were duly checked. All necessary drugs and equipment were kept ready. Difficult airway cart and all resuscitation equipment and drugs were kept ready. The patients, who were selected for the study depending on the exclusion and inclusion criteria, were allocated into 2 groups-

1. Group-E: Patients receiving etomidate and fentanyl

2. Group-D: Patients receiving dexmedetomidine and fentanyl

Intravenous (IV) access was secured with 18 G IV cannula under aseptic precautions. Blood samples were taken for the estimation of pre-operative Serum Cortisol. Intravenous fluid was started. Patients were then assisted to lie prone on the procedure table with a soft wedge under their right shoulder, right thigh flexed, head turned to the right side ( $45 \mathrm{deg}$.) on pillow avoiding compression of the dependent (left) eye.

NIBP, ECG, Pulse Oximeter (Sp02), BIS monitor were attached.

Supplemental oxygen was given to the patients via a nasal cannula at a rate of $2 \mathrm{~L} / \mathrm{min}$. A mouth guard was inserted. All baseline haemodynamic parameters were documented. All the patients were pre-medicated with Inj. glycopyrrolate $(0.2$ $\mathrm{mg}$ ) IV and Inj. fentanyl (1-2 mcg/ kg). Group-E patients were given a bolus dose of etomidate @ $0.15-0.2 \mathrm{mg} / \mathrm{kg}$ and then infusion of etomidate was started @ 0.01-0.03 mg/kg/min to attain a BIS value of 70 and maintain it during the procedure. Group-D patients were given bolus of dexmedetomidine of about $1 \mathrm{mcg} / \mathrm{kg}$ over 10 minutes and then infusion was started @ 0.4-1 mcg/ $/ \mathrm{kg} / \mathrm{min}$ to attain a BIS value of 70 and maintain that throughout the procedure. Induction time (i.e., the time from start of bolus injection to the time at which a BIS value of 70 was attained) was noted. Inj. hyoscine $20 \mathrm{mg}$ IV was given to patients prior to insertion of the guide wire to facilitate sphincter dilatation. All haemodynamic parameters were continuously monitored intra-operatively. Occurrence of any adverse haemodynamic effects were noted and managed accordingly. During the procedure the patients were monitored for occurrence of any adverse effects. These adverse effects were documented and managed adequately. All patients were given Inj. ondansetron $0.15 \mathrm{mg} / \mathrm{kg}$ slow IV for prophylaxis of postoperative nausea and vomiting (PONV). At the completion of the procedure, the drug infusion was stopped. Recovery time was recorded from the cessation of drug infusion till BIS score reaches $\geq 90$. The patient was shifted to the post-recovery room when the BIS score was $\geq$ 90. Patients were monitored in the recovery room. They were discharged to the ward when the modified Aldrete Score was $\geq 9$. All the patients were interviewed regarding their experience relating to the procedure and anaesthesia. They were asked about level of satisfaction, Post-operative pain (VAS score) and occurrence of PONV. After 12 hours of the procedure, the patient's blood sample was sent for Serum Cortisol. Physician's satisfaction was also assessed. Patients 
were adequately monitored in the ward for early detection of post-ERCP complications.

The data were analysed using Statistical Package for Social Sciences version 22.0 for Windows [IBM Corp. Released 2011. IBM SPSS Statistics for Windows, Version 20.0. Armonk, NY: IBM Corp.] The continuous variables (Age, Height, Weight, Time regarding the onset of sedation and recovery from sedation, postoperative pain scores and serum cortisol levels) between the groups were analysed using Student's unpaired t-test. Intra-group comparison of preoperative and post-operative serum cortisol levels were analysed using paired t-test. The categorical variables such as gender distribution, ASA-physical status, haemodynamics events (Hypotension, Hypertension and Bradycardia), adverse events (apnoea, myoclonus, PONV), patient's satisfaction and physician's satisfaction were analysed using the Pearson Chi-square test. A P-value $<0.05$ was taken to be statistically significant.

\section{RESULTS}

\begin{tabular}{|c|c|c|l|l|}
\hline & $\begin{array}{c}\text { Group-D } \\
(\mathbf{n}=\mathbf{5 0})\end{array}$ & $\begin{array}{c}\text { Group-E } \\
(\mathbf{n}=\mathbf{5 0})\end{array}$ & $\mathbf{p}$ Value & $\begin{array}{c}\text { Statistical } \\
\text { Significance }\end{array}$ \\
\hline $\begin{array}{c}\text { Age } \\
\text { (In Years) }\end{array}$ & $\begin{array}{c}50.74 \pm \\
6.337\end{array}$ & $\begin{array}{c}51.28 \pm \\
6.095\end{array}$ & 0.001 & Not significant \\
\hline Sex (F/M) & $\begin{array}{c}25(50 \%) / \\
25(50 \%)\end{array}$ & $\begin{array}{c}24(48 \%) / \\
26(52 \%)\end{array}$ & 0.004 & Not significant \\
\hline $\begin{array}{c}\text { Weight } \\
\text { (in Kgs.) }\end{array}$ & $\begin{array}{c}56.42 \pm \\
7.089\end{array}$ & $\begin{array}{c}61.58 \pm \\
6.000\end{array}$ & 0.001 & Not significant \\
\hline $\begin{array}{c}\text { Height } \\
\text { (in cms) }\end{array}$ & $\begin{array}{c}160.06 \pm \\
7.742\end{array}$ & $\begin{array}{c}160.18 \pm \\
7.639\end{array}$ & 0.002 & Not significant \\
\hline $\begin{array}{c}\text { ASA-PS } \\
\text { (I/II) }\end{array}$ & $\begin{array}{c}24(48 \%) / \\
26(52 \%)\end{array}$ & $\begin{array}{c}20(40 \%) / \\
30(60 \%)\end{array}$ & 0.004 & Not significant \\
\hline \multicolumn{5}{|c|}{ Table 1. Demographic Data } \\
\hline
\end{tabular}

Two groups were comparable with respect to demographic data.

\begin{tabular}{|c|c|c|c|c|}
\hline & $\begin{array}{c}\text { Group-D } \\
(\mathbf{n}=\mathbf{5 0})\end{array}$ & $\begin{array}{c}\text { Group-E } \\
(\mathbf{n}=\mathbf{5 0})\end{array}$ & $\mathbf{p}$ Value & $\begin{array}{c}\text { Statistical } \\
\text { Significance }\end{array}$ \\
\hline $\begin{array}{c}\text { Onset } \\
\text { (In Seconds) }\end{array}$ & $\begin{array}{c}874.75 \pm \\
80.68\end{array}$ & $\begin{array}{c}84.59 \pm \\
3.69\end{array}$ & 0.000 & Significant \\
\hline $\begin{array}{c}\text { Recovery } \\
\text { (In Seconds) }\end{array}$ & $\begin{array}{c}586.51 \pm \\
104.51\end{array}$ & $\begin{array}{c}494.05 \pm \\
44.57\end{array}$ & 0.000 & Significant \\
\hline
\end{tabular}

Table 2. Comparison of Onset and Recovery Time of Sedation Between the Two Study Groups

There was significant difference between the times of onset of sedation as well as recovery from sedation between the two groups. Onset as well as recovery was significantly earlier in the group receiving etomidate-fentanyl.

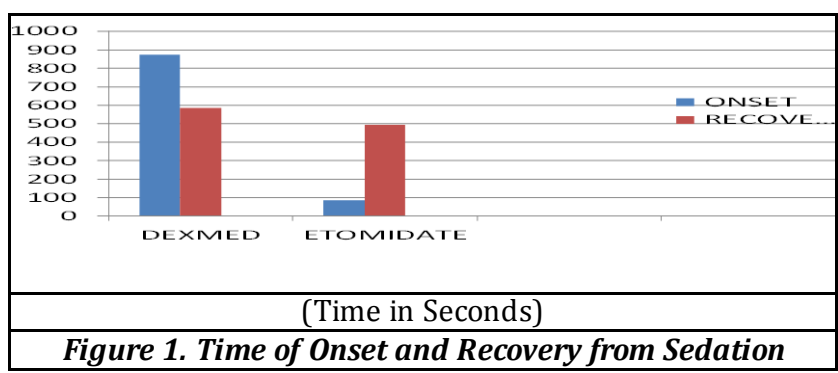

Onset and recovery were faster in etomidate group compared to dexmedetomidine group.

\begin{tabular}{|c|c|c|c|c|}
\hline & $\begin{array}{c}\text { Group-D } \\
(\mathbf{n}=\mathbf{5 0})\end{array}$ & $\begin{array}{c}\text { Group-E } \\
(\mathbf{n = 5 0 )}\end{array}$ & $\mathbf{p}$ Value & $\begin{array}{c}\text { Statistical } \\
\text { Significance }\end{array}$ \\
\hline $\begin{array}{c}\text { Hypotension } \\
(\text { Yes/No) }\end{array}$ & $\begin{array}{c}1(2 \%) / \\
49(98 \%)\end{array}$ & $\begin{array}{c}0 / \\
50(100 \%)\end{array}$ & 0.315 & $\begin{array}{c}\text { Not } \\
\text { Significant }\end{array}$ \\
\hline $\begin{array}{c}\text { Hypertension } \\
(\text { Yes/No) }\end{array}$ & $\begin{array}{c}6(12 \%) / \\
44(88 \%)\end{array}$ & $\begin{array}{c}0 / \\
50(100 \%)\end{array}$ & 0.012 & Significant \\
\hline $\begin{array}{c}\text { Bradycardia } \\
\text { (Yes/No) }\end{array}$ & $\begin{array}{c}3(6 \%) / \\
47(94 \%)\end{array}$ & $\begin{array}{c}0 / \\
50(100 \%)\end{array}$ & 0.079 & $\begin{array}{c}\text { Not } \\
\text { Significant }\end{array}$ \\
\hline \multicolumn{6}{|c|}{ Table 3. Comparison of Haemodynamic Parameters } \\
Between the Two Study Groups
\end{tabular}

There was a significant incidence of hypertension in D group.

\begin{tabular}{|c|c|c|c|c|}
\hline & $\begin{array}{l}\text { Group-D } \\
(n=50)\end{array}$ & $\begin{array}{l}\text { Group-E } \\
(n=50)\end{array}$ & p value & $\begin{array}{c}\text { Statistical } \\
\text { Significance }\end{array}$ \\
\hline $\begin{array}{c}\text { Apnoea } \\
\text { (Yes/No) }\end{array}$ & $\begin{array}{c}1(2 \%) / 49 \\
(98 \%)\end{array}$ & $\begin{array}{c}1(2 \%) / \\
49(98 \%)\end{array}$ & 1.000 & Not Significant \\
\hline $\begin{array}{c}\text { Myoclonus } \\
\text { (Yes/No) }\end{array}$ & $\begin{array}{c}0 / 50 \\
(100 \%)\end{array}$ & $\begin{array}{l}5(10 \%) / \\
45(90 \%)\end{array}$ & 0.022 & Significant \\
\hline $\begin{array}{c}\text { P.O.N.V. } \\
\text { (Yes/No) }\end{array}$ & $\begin{array}{c}2(4 \%) / 48 \\
(96 \%)\end{array}$ & $\begin{array}{l}6(12 \%) / \\
44(88 \%)\end{array}$ & 0.140 & Not Significant \\
\hline \begin{tabular}{|c|} 
Post- \\
Operative \\
Pain (VAS)
\end{tabular} & $\begin{array}{c}2.10 \pm \\
0.678\end{array}$ & $\begin{array}{l}3.46 \pm \\
0.676\end{array}$ & 0.131 & Not Significant \\
\hline
\end{tabular}

There was a significant incidence of myoclonus in $\mathrm{E}$ group.

\begin{tabular}{|c|c|c|c|}
\hline & $\begin{array}{c}\text { Group D } \\
(n=50)\end{array}$ & $\begin{array}{l}\text { Group-E } \\
(n=50)\end{array}$ & \begin{tabular}{|c|} 
p Values \\
(Inter-Group \\
Analysis) \\
\end{tabular} \\
\hline $\begin{array}{l}\text { Pre-Op. Cortisol } \\
\text { (mcg/dl) }\end{array}$ & $13.41 \pm 0.81$ & $13.57 \pm 0.83$ & 0.698 \\
\hline $\begin{array}{c}\text { Post-0p. Cortisol } \\
(\mathrm{mcg} / \mathrm{dl})\end{array}$ & $13.40 \pm 0.81$ & $13.54 \pm 0.70$ & 0.710 \\
\hline $\begin{array}{l}\text { p Values (Intra- } \\
\text { Group Analysis of } \\
\text { Pre-Op and Post- } \\
\text { Op Parameters) }\end{array}$ & 0.731 & 0.734 & \\
\hline \multicolumn{4}{|c|}{\begin{tabular}{|} 
Pre-operative as well as post-operative serum cortisol levels \\
between the two groups (Inter-group) were analysed using \\
Student's unpaired t-test. Again, the intra-group comparisons \\
were done between the pre-operative and post-operative \\
serum cortisol levels in each group using paired t-test. \\
P $<0.05$, not significant. \\
\end{tabular}} \\
\hline $\begin{array}{r}\text { Table 5. Pre-O } \\
\text { Ser }\end{array}$ & $\begin{array}{l}\text { rative And } \\
\text { n Cortisol ir }\end{array}$ & $\begin{array}{l}12 \text { Hours Po } \\
\text { I Two Group }\end{array}$ & Operative \\
\hline
\end{tabular}

There was no significant difference between the preoperative and 12-hour post-operative levels of serum cortisol in the group of patients who received etomidate.

\begin{tabular}{|c|c|c|c|c|}
\hline $\begin{array}{c}\text { Patient } \\
\text { Satisfaction }\end{array}$ & \begin{tabular}{|c|} 
Group-D \\
$(\mathrm{n}=50)$
\end{tabular} & $\begin{array}{l}\text { Group-E } \\
(n=50)\end{array}$ & p Value & $\begin{array}{c}\text { Statistical } \\
\text { Significance }\end{array}$ \\
\hline Poor (1) & $2(4 \%)$ & $6(12 \%)$ & \multirow[b]{3}{*}{0.244} & \multirow[b]{3}{*}{ Not significant } \\
\hline Fair (2) & $18(36 \%)$ & $13(26 \%)$ & & \\
\hline Good (3) & $30(60 \%)$ & $31(62 \%)$ & & \\
\hline \multicolumn{5}{|c|}{ Table 6. Comparison in Level of Patient's Satisfaction } \\
\hline
\end{tabular}

There was no significant difference with respect to the level of patient's satisfaction between the two study groups. 


\begin{tabular}{|c|c|c|c|c|}
\hline $\begin{array}{c}\text { Physician } \\
\text { Satisfaction }\end{array}$ & $\begin{array}{c}\text { Group-D } \\
(n=50)\end{array}$ & $\begin{array}{l}\text { Group-E } \\
(n=50)\end{array}$ & p Value & $\begin{array}{c}\text { Statistical } \\
\text { Significance }\end{array}$ \\
\hline Poor (1) & $1(2 \%)$ & $6(12 \%)$ & \multirow[b]{3}{*}{0.091} & \multirow[b]{3}{*}{ Not significant } \\
\hline Fair (2) & $18(36 \%)$ & $12(24 \%)$ & & \\
\hline Good (3) & $31(62 \%)$ & $32(64 \%)$ & & \\
\hline & & $\begin{array}{l}\text { arison } \\
\text { Satisf }\end{array}$ & $\begin{array}{l}\text { ivel } \\
\text { on }\end{array}$ & ysici \\
\hline
\end{tabular}

There was no significant difference with respect to the level of physician's satisfaction between the two study groups.

\section{DISCUSSION}

ERCP is a non-operating room day care procedure. Painless endoscopy will improve the patient's compliance for ERCP and fasten the diagnosis, help treatment of a few biliary pancreatic diseases and help palliation in inoperable cases. ${ }^{[10,11]}$

Bispectral index (BIS) is used to measure the level of sedation. BIS is a reasonable way to monitor the depth of sedation in patients receiving sedation/general anaesthesia. It ensures proper titration of anaesthetic agents and helps to avoid adverse effects due to overdose as well as avoid awareness due to inappropriate dosing. ${ }^{[12-14]}$

In the present study the two study groups were comparable in terms of demographic data.

There was a significant difference in the time of onset (time required attain a BIS score of 70 ) (p-value 0.000 ) and time of recovery (time to attain a BIS score of 90 ) ( $p$-value 0.000 ) between the two groups. There was significantly earlier onset of sedation as well as earlier recovery from sedation in etomidate-fentanyl group. Thus, it was found that etomidate-fentanyl combination resulted in earlier onset and shorter duration of sedation, consistent with the study carried out by El-Shmaa NS and El-Baradey GF in the year 2014.[15]

\section{Possible reasons behind the above results are ${ }^{[16]}$}

- Short initial distribution half-life of etomidate.

- Rapid clearance by liver.

- Etomidate is rapidly metabolised by liver into inactive by-products.

- $\quad$ Rapid renal and biliary clearance of the metabolites.

Rise or fall of Mean Arterial Pressure (MAP) by $\geq 20 \%$ from baseline value of MAP was considered as hypertension or hypotension and bradycardia when heart rate was $<60$ / minute. In a pre-study trial, high incidence of hypertension was found with dexmedetomidine given as a rapid infusion. ${ }^{[17]}$ Though dexmedetomidine is a $\alpha 2$ selective agonist ( $\alpha 1: \alpha 2=1: 1600$, approximately), $\alpha 1$ effects may be seen with high plasma concentrations or high infusion rate of the drug.[16] So, in our study, the loading dose of dexmedetomidine was given over 10 minutes which conform with the study done by Xu J et al in 2015.[18] We found a significant occurrence of hypertension in the group receiving dexmedetomidine-fentanyl ( $p$-value was 0.012). This hypertension mostly occurred after giving the loading dose of dexmedetomidine/just after the onset of sedation and gradually settled over time. No active intervention was needed for management of this hypertension. The possible cause of this hypertension was $\alpha 1$ mediated vasoconstriction in high plasma concentrations/at high infusion rates of dexmedetomidine. There was no statistically significant difference in the incidences of hypotension and bradycardia between the two study groups. Incidence of hypotension was not significant in either of the two study groups. Etomidate lacks effect on the sympathetic nervous system and on the function of baroreceptors, so it is haemodynamically stable.[16] Thus, etomidate administration for sedation during ERCP resulted in more stable haemodynamics and shorter recovery. This finding was consistent with the study done by Toklu S, et al in the year 2009.[19] Dexmedetomidine is also cardiostable in nature. It can occasionally cause hypotension but only with large intravenous loading doses.[16,20] Use of dexmedetomidine was found to maintain haemodynamic stability, as it was seen in a study by Patel CR et al.[21]

There was no significant difference in the incidence of apnoea between the two groups. This observation was consistent with the fact that both etomidate and dexmedetomidine are known to cause little/no depression in ventilation.[16,22] There was no significant difference in the incidences of post-operative nausea and vomiting between the two study groups. Possible cause being, all patients received Inj. ondansetron towards the end of the procedure. Post-operative pain, as assessed with the Visual analogue scale (VAS), was comparable in both the groups. Patients of both groups were seen to experience mild pain in the postoperative period. This was probably due to the administration of fentanyl in all patients irrespective of their group of allocation. Fentanyl causes analgesia by $\mu$ opioid receptor mediated direct inhibition of the ascending transmission of nociceptive stimulus from spinal cord dorsal horn. ${ }^{[23]}$ Although there was no significant difference ( $p$-value $=0.131$ ) between the incidence of post-operative pain in the two groups, the VAS Score in Group-D was slightly lower than Group-E. This could be because dexmedetomidine has an inherent analgesic effect mediated through stimulation of $\alpha 2 \mathrm{C} / 2 \mathrm{~A}$ receptor in dorsal horn and by directly suppressing pain transmission by reducing release of pro-nociceptive transmitters and hyperpolarization of interneurons,[16] whereas etomidate has no analgesic effect of its own. Myoclonus is a prominent adverse effect experienced during the induction of anaesthesia with etomidate. The incidence of myoclonus has been reported to be as high as $50-80 \%$, especially if etomidate is used without premedication. ${ }^{[24]}$ The incidence of myoclonus after induction of sedation using etomidate can be reduced by using midazolam, fentanyl or a combination of midazolam-fentanyl as pre-treatment.[24,25] In our study $10 \%$ of the patients ( 5 out of 50 patients) induced with etomidate experienced myoclonus. This was a significant finding of the study ( $p$-value $=0.022$ ).

Use of etomidate has been known to result in adrenocortical dysfunction due to dose dependent reversible inhibition of $11 \beta$ hydroxylase, leading to decreased biosynthesis of cortisol. Clinical impact of this adrenal suppressive effect is doubtful.[16] However, the serum cortisol levels remain within the normal range and dysfunction resolves within 12-24 hours of using the drug, ${ }^{[7-9]}$ as it has been shown in multiple studies. There was no significant difference between the pre-operative and 12-hour postoperative serum cortisol between the two groups. The preoperative and 12-hour post-operative serum cortisol in 
Group-E was also comparable ( $\mathrm{p}$-value $=0.734$ ). This finding was consistent with the study done by Srivastava et al. ${ }^{[7]}$

There was no significant difference between the two study groups with respect to the level of patient and physician satisfaction.

\section{CONCLUSION}

Etomidate-fentanyl combination for ERCP resulted in earlier onset and early recovery from sedation with stable haemodynamics when compared to dexmedetomidinefentanyl combination.

\section{REFERENCES}

[1] Almadi MA, Barkun JS, Barkun AN. Management of suspected stones in the common bile duct. CMAJ 2012;184(8):884-92.

[2] Byrne MF. Gallstone pancreatitis - who really needs an ERCP? Can J Gastroenterol 2006;20(1):15-7.

[3] Baillie J. Advances in endoscopy: current developments in diagnostic and therapeutic endoscopy. Gastroenterol Hepatol (N Y) 2010;6(2):903.

[4] Amornyotin S. Sedation and monitoring for gastrointestinal endoscopy. World J Gastrointest Endosc 2013;5(2):47-55.

[5] Chainaki IG, Manolaraki MM, Paspatis GA. Deep sedation for endoscopic retrograde cholangiopancreatography. World J Gastrointest Endosc 2011;3(2):34-9.

[6] Goudra BG, Singh PM, Sinha AC. Outpatient endoscopic retrograde cholangiopancreatography: safety and efficacy of anesthetic management with a natural airway in 653 consecutive procedures. Saudi J Anaesth 2013;7(3):259-65.

[7] Srivastava S, Ghosh S, Bhattacharya D, et al. Cortisol lowering action and cardiovascular stability of etomidate: a comparison with propofol in controlled hypertensives. Journal of Evolution of Medical and Dental Sciences 2015;75(4):13016-24.

[8] Schenarts CL, Burton JH, Riker RR. Adrenocortical dysfunction following etomidate induction in emergency department patients. Acad Emerg Med 2001;8(1):1-7.

[9] Pandey AK, Makhija N, Chauhan S, et al. Effects of etomidate and propofol induction on haemodynamic and endocrine response in patients undergoing coronary artery bypass surgery on cardiopulmonary bypass. World J Cardiovasc Surg 2012;2:48-53.

[10] Adas G, Kemik A, Adas M, et al. Metabolic and inflammatory responses after ERCP. Int J Biomed Sci 2013;9(4):237-42.

[11] Kapoor H. Anaesthesia for endoscopic retrograde cholangiopancreatography. Acta Anaesthesiol Scand 2011;55(8):918-26.
[12] Brown EN, Solt K, Purdon PL, et al. Monitoring brain state during general anesthesia and sedation. In: Miller RD, edr. Miller's Anesthesia. $8^{\text {th }}$ edn. Elsevier Sauders 2015: p. 1524-39.

[13] Sinha PK, Koshy T. Monitoring devices for measuring the depth of anaesthesia-an overview. Indian Journal of Anaesthesiology 2007;51(5):365-81.

[14] Sohn HM, Ryu JH. Monitored anesthesia care in and outside the operating room. Korean J Anesthesiol 2016;69(4):319-26.

[15] El-Shmaa NS, El-Baradey GF. The efficacy of etomidate-fentanyl versus dexmedetomidineketamine for procedural sedation and analgesia during upper endoscopy and biopsy: a prospective randomized study. J Anaesth Clin Res 2014;5:480.

[16] Vuyk J, Sitsen E, Reekers M. Intravenous anesthetics. Chap - 30. In: Miller RD, editor. Miller's Anesthesia. $8^{\text {th }}$ edn. Elsevier Saunders 2015: p. 821-60.

[17] Naaz S, Ozair E. Dexmedetomidine in current anaesthesia practice - a review. J Clin Diagn Res 2014;8(10):GE01-GE04.

[18] $\mathrm{Xu}$ J, Jin C, Cui $\mathrm{X}$, et al. Comparison of dexmedetomidine versus propofol for sedation after Uvulopalatopharyngoplasty. Med Sci Monit 2015;21: 2125-33.

[19] Toklu S, Iyilikci L, Gonen C, et al. Comparison of etomidate-remifentanil and propofol-remifentanil sedation in patients scheduled for colonoscopy. Eur J Anaesthesiol 2009;26(5):370-6.

[20] Ahmed SS, Unland T, Slaven JE, et al. High dose dexmedetomidine: effective as a sole agent sedation for children undergoing MRI. International Journal of Pediatrics Article ID 397372, 2015;2015: p. 7.

[21] Patel CR, Engineer SR, Shah BJ, et al. Effect of intravenous infusion of dexmedetomidine on perioperative haemodynamic changes and postoperative recovery: a study with entropy analysis. Indian J Anaesth 2012;56(6):542-6.

[22] Arain SR, Ebert TJ. The efficacy, side effects and recovery characteristics of dexmedetomidine versus propofol when used for intraoperative sedation. Anesth Analg 2002;95(2):461-6.

[23] Davis MP. Fentanyl for breakthrough pain: a systematic review. Expert Rev Neurother 2011;11(8):1197-216.

[24] Isitemiz I, Uzman S, Toptas M, et al. Prevention of etomidate-induced myoclonus: which is superior: fentanyl, midazolam or a combination? A retrospective comparative study. Med Sci Monit 2014;20:262-7.

[25] Hüter L, Schreiber T, Gugel $M$, et al. Low-dose intravenous midazolam reduces etomidate-induced myoclonus: a prospective, randomized study in patients undergoing elective cardioversion. Anesth Analg 2007;105(5):1298-302. 